\title{
Effect of Substituents of Cerium Pyrazolates and Pyrrolates on Carbon Dioxide Activation
}

\author{
Uwe Bayer, Adrian Jenner, Jonas Riedmaier, Cäcilia Maichle-Mössmer (10) and Reiner Anwander *(1)
}

check for updates

Citation: Bayer, U.; Jenner, A.;

Riedmaier, J.; Maichle-Mössmer, C.; Anwander, R. Effect of Substituents of Cerium Pyrazolates and Pyrrolates on Carbon Dioxide Activation. Molecules 2021, 26, 1957. https://doi.org/ 10.3390/molecules26071957

Academic Editor: Elena V. Grachova

Received: 12 March 2021

Accepted: 24 March 2021

Published: 31 March 2021

Publisher's Note: MDPI stays neutral with regard to jurisdictional claims in published maps and institutional affiliations.

Copyright: (c) 2021 by the authors. Licensee MDPI, Basel, Switzerland. This article is an open access article distributed under the terms and conditions of the Creative Commons Attribution (CC BY) license (https:// creativecommons.org/licenses/by/ $4.0 /)$.
Institute of Inorganic Chemistry, Eberhard Karls Universität Tübingen, Auf der Morgenstelle 18, 72076 Tübingen, Germany; uwe.bayer@uni-tuebingen.de (U.B.); adrian.jenner@student.uni-tuebingen.de (A.J.); jonas.riedmaier@student.uni-tuebingen.de (J.R.); caecilia.maichle-moessmer@uni-tuebingen.de (C.M.-M.)

* Correspondence: reiner.anwander@uni-tuebingen.de

\begin{abstract}
Homoleptic ceric pyrazolates $(\mathrm{pz}) \mathrm{Ce}\left(\mathrm{R} \mathrm{R}^{\prime} \mathrm{pz}\right)_{4}\left(\mathrm{R}=\mathrm{R}^{\prime}=t \mathrm{Bu} ; \mathrm{R}=\mathrm{R}^{\prime}=\mathrm{Ph} ; \mathrm{R}=t \mathrm{Bu}, \mathrm{R}^{\prime}=\mathrm{Me}\right)$ were synthesized by the protonolysis reaction of $\mathrm{Ce}\left[\mathrm{N}\left(\mathrm{SiHMe}_{2}\right)_{2}\right]_{4}$ with the corresponding pyrazole derivative. The resulting complexes were investigated in their reactivity toward $\mathrm{CO}_{2}$, revealing a significant influence of the bulkiness of the substituents on the pyrazolato ligands. The efficiency of the $\mathrm{CO}_{2}$ insertion was found to increase in the order of $t \mathrm{Bu}_{2} \mathrm{pz}<\mathrm{Ph}_{2} \mathrm{pz}<t \mathrm{BuMepz}<\mathrm{Me}_{2} \mathrm{pz}$. For comparison, the pyrrole-based ate complexes $\left[\mathrm{Ce}_{2}(\text { pyr })_{6}(\mu \text {-pyr })_{2}(\text { thf })_{2}\right]\left[\mathrm{Li}(\mathrm{thf})_{4}\right]_{2}($ pyr $=$ pyrrolato) and $\left[\mathrm{Ce}(\mathrm{cbz})_{4}(\mathrm{thf})_{2}\right]\left[\mathrm{Li}(\mathrm{thf})_{4}\right](\mathrm{cbz}=$ carbazolato $)$ were obtained via protonolysis of the cerous ate complex $\mathrm{Ce}\left[\mathrm{N}\left(\mathrm{SiHMe}_{2}\right)_{2}\right]_{4} \mathrm{Li}(\mathrm{thf})$ with pyrrole and carbazole, respectively. Treatment of the pyrrolate/carbazolate complexes with $\mathrm{CO}_{2}$ seemed promising, but any reversibility could not be observed.
\end{abstract}

Keywords: cerium; pyrazoles; pyrroles; carbazoles; carbon dioxide

\section{Introduction}

Rare-earth-metal complexes are capable of efficiently activating carbonylic compounds including carbon dioxide [1-6]. Due to its environmental impact, atmospheric $\mathrm{CO}_{2}$ management and, in particular, sustainable solutions for $\mathrm{CO}_{2}$ emission control evolved as a top-priority issue in academic and industrial research [7-11]. On the one hand, this can be realized by capturing and storing carbon dioxide with tailor-made surface-reactive materials [12-16]. On the other hand, the use of $\mathrm{CO}_{2}$ as a cheap, abundant, and nontoxic $\mathrm{C} 1$ building block in the synthesis of higher-value chemicals is a main goal in sustainable chemistry [17-23]. For example, rare-earth metals have successfully been studied as catalysts for the copolymerization of carbon dioxide and epoxides to yield polycarbonates [24-30]. Various rare-earth-metal-based (pre)catalysts are known to promote the catalytic cycloaddition of carbon dioxide and epoxide-producing cyclic carbonates, which then, in case of propylene carbonate, can be used as electrolyte solvent in lithium-ion batteries [30-37]. However, these complexes often lack the catalytic activity and superb performance of zinc or cobalt-based systems [4].

We have recently described the application of homoleptic ceric pyrazolate $\left[\mathrm{Ce}\left(\mathrm{Me}_{2} \mathrm{pz}\right)_{4}\right]_{2}$ in the catalytic cycloaddition of carbon dioxide and epoxides as well as the reversible capture of $\mathrm{CO}_{2}[38,39]$. To study the scope and efficiency of such pyrazolate-promoted $\mathrm{CO}_{2}$ insertion reactions, we extended our study with a broader comparison to differently substituted pyrazole derivatives as ligands for cerium(IV). Since we hypothesized that the basicity of the ligand plays a crucial role in any reversible $\mathrm{CO}_{2}$ uptake, we also envisaged different $N$-proligands. Pyrroles feature a mono-aza five-membered ring, exhibiting a $\mathrm{p} K_{\mathrm{a}}$ value that is larger than that of pyrazoles, but close to silylamines (Figure 1) [40]. Metal silylamides, however, were shown to engage in a cascade of reactions with $\mathrm{CO}_{2}$, ultimately affording metal siloxides [41-43]. Whereas pyrrole-derived pincer-type ligands are quite popular in rare-earth-metal coordination chemistry [44-51], examples of pure pyrrolyl ligands have 
remained scarce [52-55]. Likewise, rare-earth-metal complexes bearing a carbazolyl ligand have been reported [56-62]. As a pyrrole derivative, carbazole exhibits a $p K_{a}$ value that matches that of pyrazole (Figure 1).

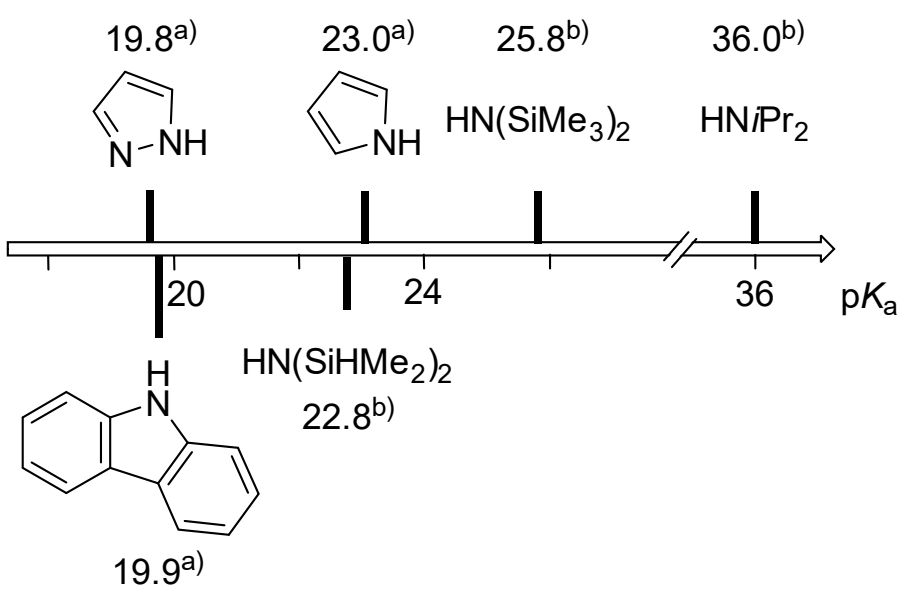

Figure 1. $\mathrm{p} K_{\mathrm{a}}$ values of the different $N$-proligands $[40,63,64]$. a) Determined in DMSO, ${ }^{\mathrm{b})}$ determined in THF.

\section{Results and Discussion}

\subsection{Homoleptic Ceric Pyrazolates}

Homoleptic cerium di-tert-butyl pyrazolate $\mathrm{Ce}\left(t \mathrm{Bu}_{2} \mathrm{pz}\right)_{4}(\mathbf{1})$ was synthesized by treatment of $\mathrm{Ce}\left[\mathrm{N}\left(\mathrm{SiHMe}_{2}\right)_{2}\right]_{4}$ with four equivalents of $t \mathrm{Bu} \mathrm{u}_{2} \mathrm{pzH}$ as previously described (Scheme 1) [65]. Likewise, $\mathrm{Ce}\left(\mathrm{Ph}_{2} \mathrm{pz}\right)_{4}(2)$ and $\mathrm{Ce}(t \mathrm{BuMepz})_{4}$ (3) were synthesized using the corresponding pyrazole (Scheme 1). The ${ }^{1} \mathrm{H}$ NMR spectrum of 2 shows a singlet for the proton in the pyrazolato backbone at $7.11 \mathrm{ppm}$ and two multiplets at 6.91 and $7.78 \mathrm{ppm}$ for the aromatic protons (Figure S1, Supporting Information). In contrast to the complexes bearing symmetric pyrazolato ligands, compound 3 with the asymmetric 3-tert-butyl-5-methyl pyrazolato ligand could not be obtained as a crystalline material, but as a dark red sticky solid upon removing the volatiles in vacuo. The general composition of $\left[\mathrm{Ce}(t \mathrm{BuMepz})_{4}\right]_{n}$ was confirmed by ${ }^{1} \mathrm{H}$ NMR spectroscopy showing singlets at $1.24 \mathrm{ppm}$ for the $t \mathrm{Bu}$ groups, at $2.22 \mathrm{ppm}$ for the methyl groups, and at $6.15 \mathrm{ppm}$ for the $\mathrm{C}-\mathrm{H}$ proton of the five-membered pyrazole ring (Figure S2, Supporting Information). However, elemental analysis displayed some extent of impurification, indicated by an increased carbon value most likely stemming from retained solvent.

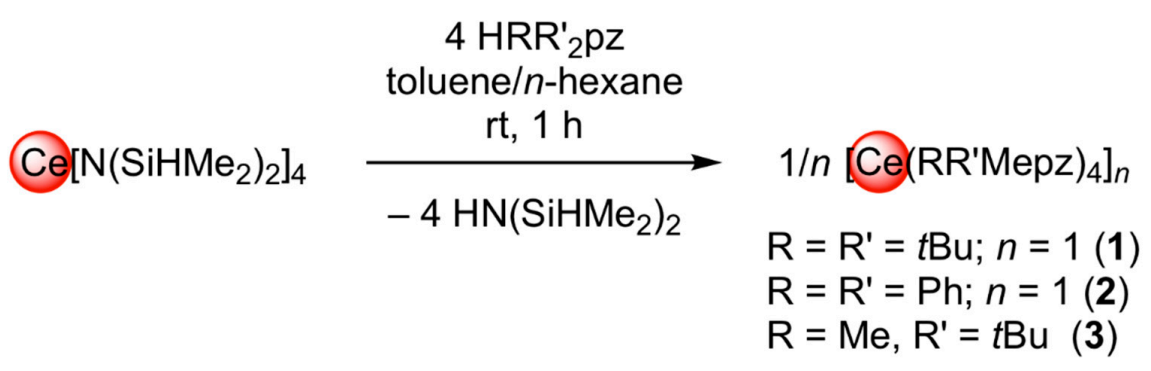

Scheme 1. Synthesis of ceric pyrazolates 1 to 3.

Crystals of complex 2 suitable for an X-ray diffraction (XRD) study could be obtained from a concentrated solution in toluene. The crystal structure revealed an eight-coordinate cerium center surrounded by four $\eta^{2}$-coordinated diphenylpyrazolato moieties (Figure 2). The Ce1-N distances (2.3381(16) to 2.3790(16) $\AA$ ) are comparable to other terminal $\mathrm{Ce}^{\mathrm{IV}}-\mathrm{N}(\mathrm{pz})$ bonds (1: 2.322(4) to 2.365(4) $\AA$; Ce(Me2 $\mathrm{pz})_{4}: 2.319(3)$ to 2.384(2) $\AA$ ) [65]. 


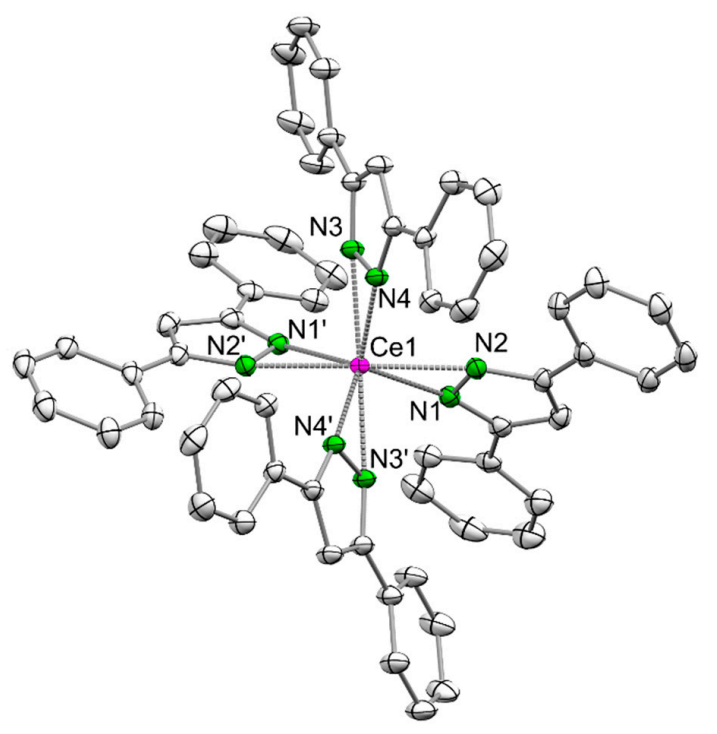

Figure 2. Crystal structure of $\mathrm{Ce}\left(\mathrm{Ph}_{2} \mathrm{pz}\right)_{4}$ (2). Ellipsoids are shown at the $50 \%$ probability level. Hydrogen atoms and lattice toluene are omitted for clarity. Selected interatomic distances $(\AA)$ and angles $\left({ }^{\circ}\right)$ : Ce1-N1 2.3790(16), Ce1-N2 2.3381(16), Ce1-N3 2.3409(15), Ce1-N4 2.3575(16); N1-Ce1-N3 113.41(6), N1-Ce1-N4 118.73(5), N2-Ce1-N3 96.05(6), and N2-Ce1-N4 87.76(5).

\subsection{Cerium Pyrrolates and Carbazolates}

As the synthesis pathway via protonolysis reaction of $\mathrm{Ce}\left[\mathrm{N}\left(\mathrm{SiHMe}_{2}\right)_{2}\right]_{4}$ with pyrazole emerged as a feasible route for the synthesis of homoleptic ceric pyrazolates, the envisaged pyrrolates were accessed accordingly. Unexpectedly, treatment of the silylamide with four equivalents of pyrrole did not yield any reaction. Therefore, we reacted the cerous ate complex $\mathrm{Ce}\left[\mathrm{N}\left(\mathrm{SiHMe}_{2}\right)_{2}\right]_{4} \mathrm{Li}$ (thf) [66] with four equivalents of pyrrole (Hpyr) and carbazole $(\mathrm{Hcbz})$, yielding the complexes $\left[\mathrm{Ce}_{2}(\mathrm{pyr})_{6}(\mu-\mathrm{pyr})_{2}(\mathrm{thf})_{2}\right]\left[\mathrm{Li}(\mathrm{thf})_{4}\right]_{2}(4)$ and $\left[\mathrm{Ce}(\mathrm{cbz})_{4}(\text { thf })_{2}\right]\left[\mathrm{Li}(\mathrm{thf})_{4}\right]$ (5), respectively (Scheme 2). The ${ }^{1} \mathrm{H}$ NMR spectrum of 4 shows two broadened singlets for the pyrrolato protons at 4.23 and 7.39 ppm (Figure S3, Supporting Information). For complex 5, various broadened proton signals could be detected as well but due to the paramagnetic $\mathrm{Ce} \mathrm{e}^{\mathrm{III}}$ center, assignment of the signals was inconclusive (Figure S5, Supporting Information). The persistence of ion-separated intermolecular ate complexes in THF- $d_{8}$ was evidenced by ${ }^{7} \mathrm{Li}$ NMR spectroscopy $\left(4: \delta_{\mathrm{Li}}=2.0 \mathrm{ppm}\right.$; 5: $\delta_{\mathrm{Li}}=-0.3 \mathrm{ppm}$; (Figures S4 and S6, Supporting Information)) [67].

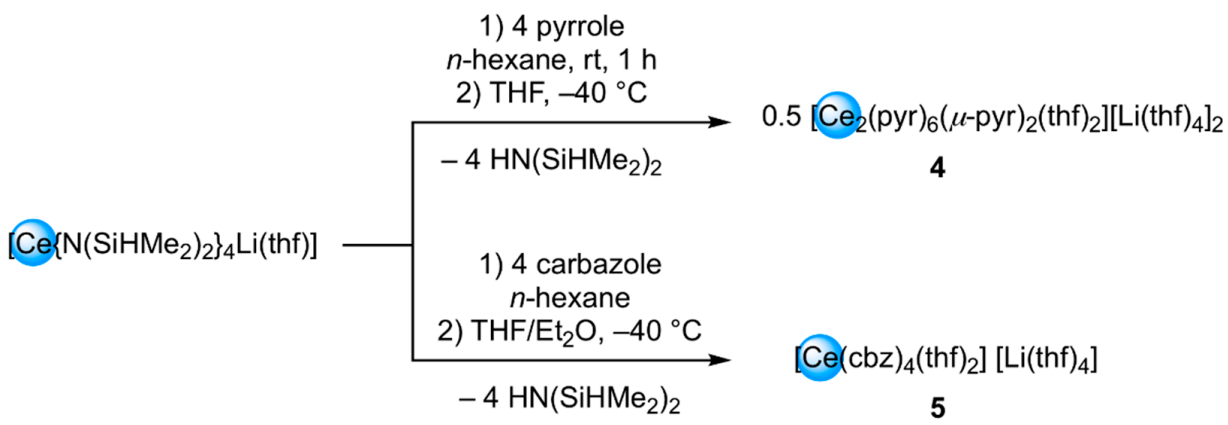

Scheme 2. Synthesis of cerous pyrrolate and carbazolate ate complexes 4 and 5 .

Crystallization from a concentrated THF solution gave 4 as colorless crystals. The crystal structure of 4 revealed a separated ion pair featuring a dicerium dianionic entity (Figure 3). Each cerium center is eight-coordinated and surrounded by three terminal pyrrolato moieties (Ce1-N 2.475(2) to 2.515(2) $\AA$ ), two bridging pyrrolato ligands connecting the cerium centers in an $\eta^{1}\left(\mathrm{Ce} 1-\mathrm{N} 4^{\prime}\right.$ 2.622(2) $\AA$ ) and ${ }^{\eta^{5}}$ fashion (Ce1-Ct 2.575(16) $\AA$ ), and one THF donor molecule. The $\mathrm{Ce}-\mathrm{N}$ distances are slightly elongated compared with 
other Ce $\mathrm{III}$ ate complexes like $\left[\mathrm{Ce}\left\{\mathrm{N}\left(\mathrm{SiHMe}_{2}\right)_{2}\right\}_{4}\right]\left[\mathrm{Li}(\mathrm{do})_{x}\right](\mathrm{do}, x=$ py, 4 ; tmeda, $2 ; 12$ crown-4, 1 and thf, 4; Ce-N 2.377(6) to 2.438(6) $\AA$ ), $\mathrm{KCe}\left[\mathrm{N}\left(\mathrm{SiHMe}_{2}\right)_{2}\right]_{4}(2.3820(12)$ to 2.4379(12) $\AA$ ), and $\left[\mathrm{Ce}\left\{\mathrm{N}\left(\mathrm{SiMe}_{3}\right)_{2}\right\}_{4}\right]\left[\mathrm{Na}\left(\mathrm{thf}_{4}\left(\mathrm{Et}_{2} \mathrm{O}\right)\right]\right.$ (Ce-N 2.434(6) to 2.448(6) $\AA$ ), due to the higher coordination number $\mathrm{CN}$ of 4 (CN 8 vs. 4) [67-69]. The $\sigma, \pi$-bridging motif of the pyrrolato ligands has been detected previously, for example, in complexes $\left[\mathrm{Me}_{2} \operatorname{In}(\mu \text {-pyr })\right]_{n}$, $\left[\mathrm{Me}_{2} \mathrm{Al}_{2}(\mu-\mathrm{Cl})\right]\left(\mu-\mathrm{Me} \mathrm{e}_{4} \mathrm{pyr}\right) \mathrm{Li},\left[\mathrm{Mg}\left\{\mu-\mathrm{C}_{4} \mathrm{H}_{2} \mathrm{~N}\left(2-\mathrm{CH}_{2} \mathrm{NH} t \mathrm{Bu}\right)\right\}\left\{\mathrm{N}\left(\mathrm{SiMe}_{3}\right)_{2}\right\}\right]_{2}$, and $\left(\mathrm{AlMe}_{3}\right)(\mu-$ $\left.\mathrm{C}_{4} \mathrm{H}_{3} \mathrm{~N}\right)\left[2-\mathrm{CH}_{2} \mathrm{NH}(t \mathrm{Bu}) \mathrm{Li}(\right.$ tmeda $\left.)\right]$ [70-73].
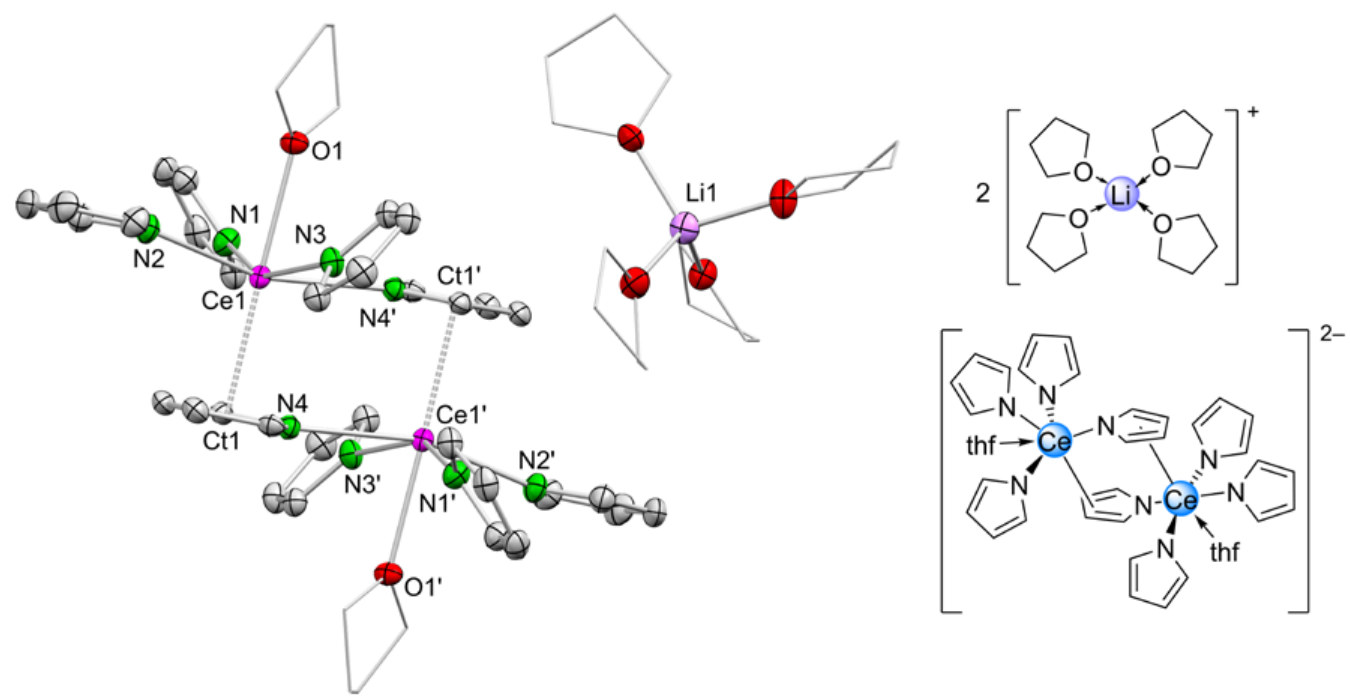

Figure 3. Crystal structure of $\left[\mathrm{Ce}_{2}(\mathrm{pyr})_{6}(\mu \text {-pyr })_{2}(\text { thf })_{2}\right]\left[\mathrm{Li}(\mathrm{thf})_{4}\right]_{2}(4)$. Ellipsoids are shown at the $50 \%$ probability level. Hydrogen atoms and the second $\left[\mathrm{Li}(\text { thf })_{4}\right]^{+}$counter ion are omitted for clarity. Selected interatomic distances $(\AA)$ and angles $\left({ }^{\circ}\right)$ : Ce1-N1 2.512(2), Ce1-N2 2.475(2), Ce1-N3 2.515(2), Ce1-N4' 2.622(2), Ce1-Ct1 2.575(16), Ce1-O1 2.5138(17); N1-Ce1-N2 97.21(7), N1-Ce1N3 153.53(8), N1-Ce1-N4 86.15(7), N1-Ce1-O1 78.80(7), and N4-Ce1'-Ct1' 97.8(5).

Complex 5 was recrystallized from a 1:1 mixture of THF and $\mathrm{Et}_{2} \mathrm{O}$ to yield off-white crystals suitable for XRD analysis. The crystal structure of $\mathbf{5}$ shows a six-coordinate cerium center surrounded by four carbazolyl ligands, two THF donor molecules and a [Li(thf $\left.)_{4}\right]^{+}$ counter ion (Figure 4). As seen before, the Ce1-N distances (2.480(4) to 2.531(4) $\AA$ ) are slightly elongated compared with other separated ion-pair type ate complexes due to the higher coordination number of 6 compared with 4 .

Targeted oxidations of the ate complexes 4 and 5 with $p$-benzoquinone led to an immediate color change to dark green and dark purple, respectively. Although indicative of a redox reaction, the isolation and characterization of a tetravalent cerium pyrrolate or carbazolate was unsuccessful. Dissolving the resulting crude product in THF- $d_{8}$ resulted in the decolorization of the solution and the obtained ${ }^{1} \mathrm{H}$ NMR spectrum showed only paramagnetically broadened and shifted signals. This play of colors clearly indicated a reduction in the putatively formed tetravalent species. The use of other solvents was not possible due to the insolubility of the cerium pyrrolates and carbazolates in nondonating solvents. 


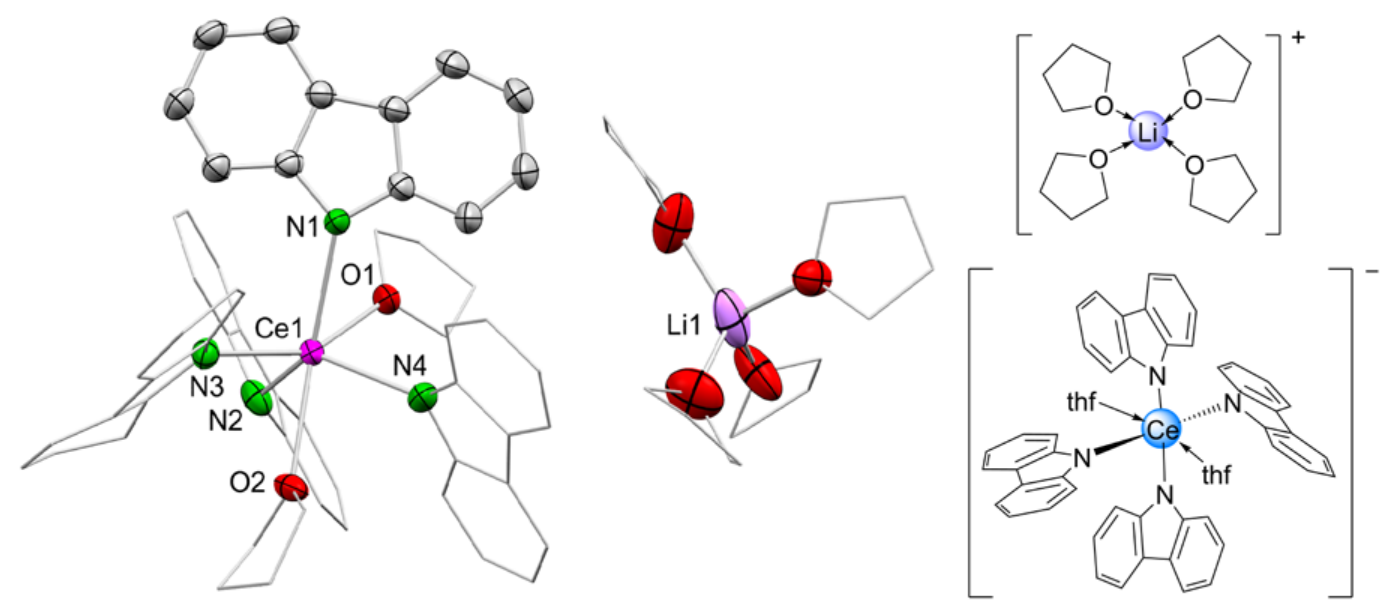

Figure 4. Crystal structure of $\left[\mathrm{Ce}(\mathrm{cbz})_{4}(\mathrm{thf})_{2}\right]\left[\mathrm{Li}(\mathrm{thf})_{4}\right](5)$. Ellipsoids are shown at the $50 \%$ probability level. Hydrogen atoms and disordered atoms are omitted for clarity. Selected interatomic distances $(\AA)$ and angles $\left({ }^{\circ}\right)$ : Ce1-N1 2.531(4), Ce1-N2 2.480(4), Ce1-N3 2.497(4), Ce1-N4 2.484(4), Ce1-O1 2.577(4), Ce1-O2 2.583(3); N1-Ce1-N2 128.14(14), N1-Ce1-N3 90.91(13), N1-Ce1-N4 92.69(13), and O1-Ce1-O2 129.06(11).

\subsection{Reactivity toward $\mathrm{CO}_{2}$}

Preliminary studies on the reactivity of the silylamide $\mathrm{Ce}\left[\mathrm{N}\left(\mathrm{SiHMe}_{2}\right)_{2}\right]_{4}$ (red color) [74] as well as $\mathrm{Ce}\left(\mathrm{NiPr}_{2}\right)_{4}$ (purple) [75] and $\mathrm{Ce}\left(\mathrm{NiPr}_{2}\right)_{4} \mathrm{Li}($ thf) (orange) [75], bearing the very basic diisopropylamido ligand (Figure 1), with $\mathrm{CO}_{2}$ resulted in an instant decolorization of the solutions and the formation of colorless precipitates. ${ }^{1} \mathrm{H}$ NMR spectroscopic measurements of the reaction mixtures provided inconclusive results. As noted in the Introduction, for rareearth-metal silylamides, the formation of siloxide species and the elimination of isocyanates via silyl migration has been previously described [41-43]. Therefore, we focused on cerium pyrazolates and pyrrolates and their reactivity toward $\mathrm{CO}_{2}$. The possible insertion of $\mathrm{CO}_{2}$ into the $\mathrm{Ce}-\mathrm{N}$ (pyrazolato) bond was examined via in situ IR spectroscopic measurements in toluene. Because compounds $\mathbf{1}$ and $\mathbf{2}$ did not display any insertion of $\mathrm{CO}_{2}$ at ambient temperature, the reactions were conducted at $-20^{\circ} \mathrm{C}$. It was shown previously for dimethyl pyrazolate $\left[\mathrm{Ce}\left(\mathrm{Me}_{2} \mathrm{pz}\right)_{4}\right]_{2}$ that the $\mathrm{CO}_{2}$ insertion is more efficient at lower temperatures [38]. These experiments revealed no (1), slow (2) and fast insertion (3), as indicated by an increasing intensity of the characteristic C-O vibrations at around 1600 to $1750 \mathrm{~cm}^{-1}$ in the DRIFT (diffuse reflectance infrared Fourier transform) spectra (Figure 5). However, the insertion processes were slower and less efficient than observed previously for the dimethyl pyrazolate $\left[\mathrm{Ce}\left(\mathrm{Me}_{2} \mathrm{pz}\right)_{4}\right]_{2}$ [38]. ${ }^{1} \mathrm{H}$ NMR spectroscopic investigations revealed only minor insertion of $\mathrm{CO}_{2}$ into the $\mathrm{Ce}-\mathrm{N}$ (pyrazolato) bond of complex 1 (Figure S7, Supporting Information). Notwithstanding, a new signal set appeared assignable to a $t \mathrm{Bu}_{2} \mathrm{pzCO}_{2}$ ligand (Figure 6), displaying two singlets at 1.02 and $1.50 \mathrm{ppm}$ for the $t \mathrm{Bu}$-groups and one singlet at $5.97 \mathrm{ppm}$ for the $\mathrm{C}-\mathrm{H}$ proton of the pyrazole backbone. For the reaction of compound 2 with $\mathrm{CO}_{2}$, the respective ${ }^{1} \mathrm{H}$ NMR spectrum showed a shift of all signals, indicating complete conversion (Figure S8, Supporting Information). However, unlike what was expected for an asymmetrically $\mathrm{CO}_{2}$-inserted pyrazolato ligand, a splitting of the phenyl signals was not detected. For the reaction of compound 3 with $\mathrm{CO}_{2}$, the formation of two signal sets with a ratio of 9:1 was observed (Figure S9, Supporting Information). Both sets displayed singlets for the $t \mathrm{Bu}$ and $\mathrm{Me}$ groups and one for the pyrazole $\mathrm{C}-\mathrm{H}$. This signal pattern might have resulted from a favorable insertion of $\mathrm{CO}_{2}$ into the methyl site of the pyrazolato ligand due to the lower steric hindrance (Figure 6). These results and previous findings clearly show that the steric demand of the substituents on the pyrazolato ligands is the key factor in the $\mathrm{CO}_{2}$-insertion reaction [38]. Therefore, the efficiency of the $\mathrm{CO}_{2}$ insertion with complexes $\left[\mathrm{Ce}\left(\mathrm{RR}^{\prime} \mathrm{pz}\right)_{4}\right]$ increases in the order of $t \mathrm{Bu}_{2} \mathrm{pz}<\mathrm{Ph}_{2} \mathrm{pz}<t \mathrm{BuMepz}<\mathrm{Me}_{2} \mathrm{pz}$. Unfortunately, any crystallization and structural elucidation of a $\mathrm{CO}_{2}$-inserted product was not successful. 
a)

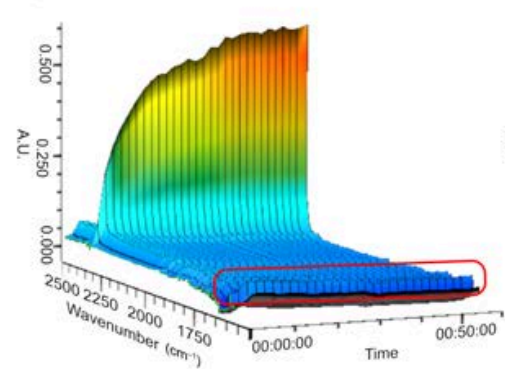

b)

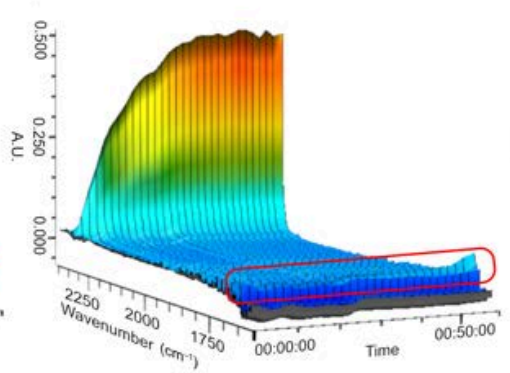

c)

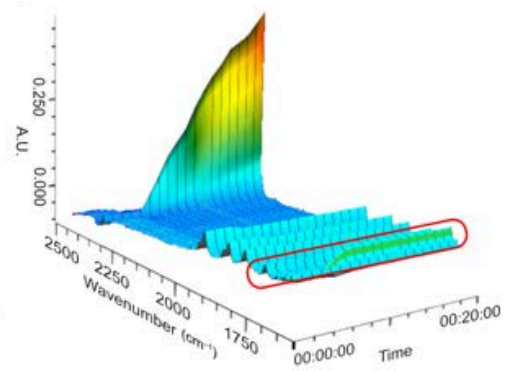

Figure 5. In situ IR spectroscopic measurements of the reaction of $\mathrm{CO}_{2}$ and (a) $\mathrm{Ce}\left(t \mathrm{Bu}_{2} \mathrm{pz}\right)_{4}(\mathbf{1}),(\mathbf{b}) \mathrm{Ce}\left(\mathrm{Ph}_{2} \mathrm{pz}\right)_{4}(\mathbf{2})$, and (c) $\mathrm{Ce}(t \mathrm{BuMepz})_{4}(3)$ at $-20^{\circ} \mathrm{C}$. The wavenumber of the $\mathrm{C}=\mathrm{O}$ band is marked with a red box.

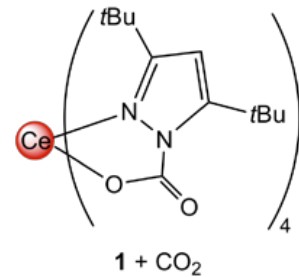

$1+\mathrm{CO}_{2}$

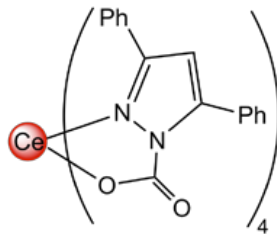

$2+\mathrm{CO}_{2}$

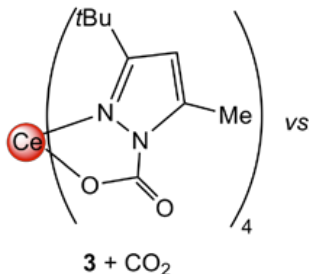

9

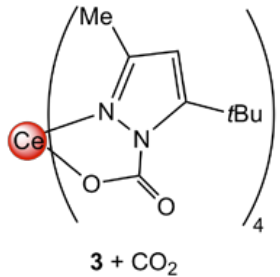

1

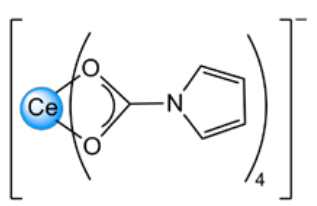

$4+\mathrm{CO}_{2}$

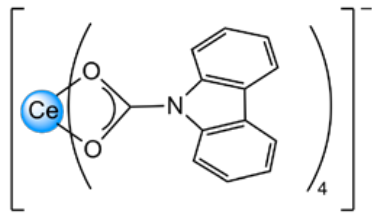

$5+\mathrm{CO}_{2}$

Figure 6. Putative insertion products of the reaction of complexes $\mathbf{1}$ to $\mathbf{5}$ with $\mathrm{CO}_{2}$.

Similarly, pyrrole-derived complexes 4 and 5 were treated with $\mathrm{CO}_{2}$ resulting in a shift of the signals in the ${ }^{1} \mathrm{H}$ NMR spectra (Figures S10 and S11, Supporting Information). For pyrrolate 4, two broadened singlets were observed at 6.82 and $9.99 \mathrm{ppm}$, indicating the formation of a carbamato-like ligand $\mathrm{CO}_{2} \cdot \mathrm{pyr}$ (Figure 6). Similar ligand formation was already found in the reaction of $n \mathrm{BuLi}$, pyrrole, and carbon dioxide [76]. The ${ }^{1} \mathrm{H}$ NMR spectrum of the reaction of carbazolate 5 with $\mathrm{CO}_{2}$ shows various paramagnetically broadened and shifted signals ruling out any conclusive interpretation. Nevertheless, the DRIFT spectra of the crude products, after removal of all volatiles under reduced pressure, clearly revealed an intense band for the $\mathrm{C}-\mathrm{O}$ vibrations at 1600 to $1750 \mathrm{~cm}^{-1}$ (Figure 7). This finding also indicated that, unlike $\left[\mathrm{Ce}\left(\mathrm{Me}_{2} \mathrm{pz}\right)_{4}\right]_{2}[38]$, the $\mathrm{CO}_{2}$ insertion into the $\mathrm{Ce}-\mathrm{N}$ (pyrrolato) bond is not reversible at ambient temperature under reduced pressure. Regrettably, a structural elucidation of the reaction products was not feasible. 


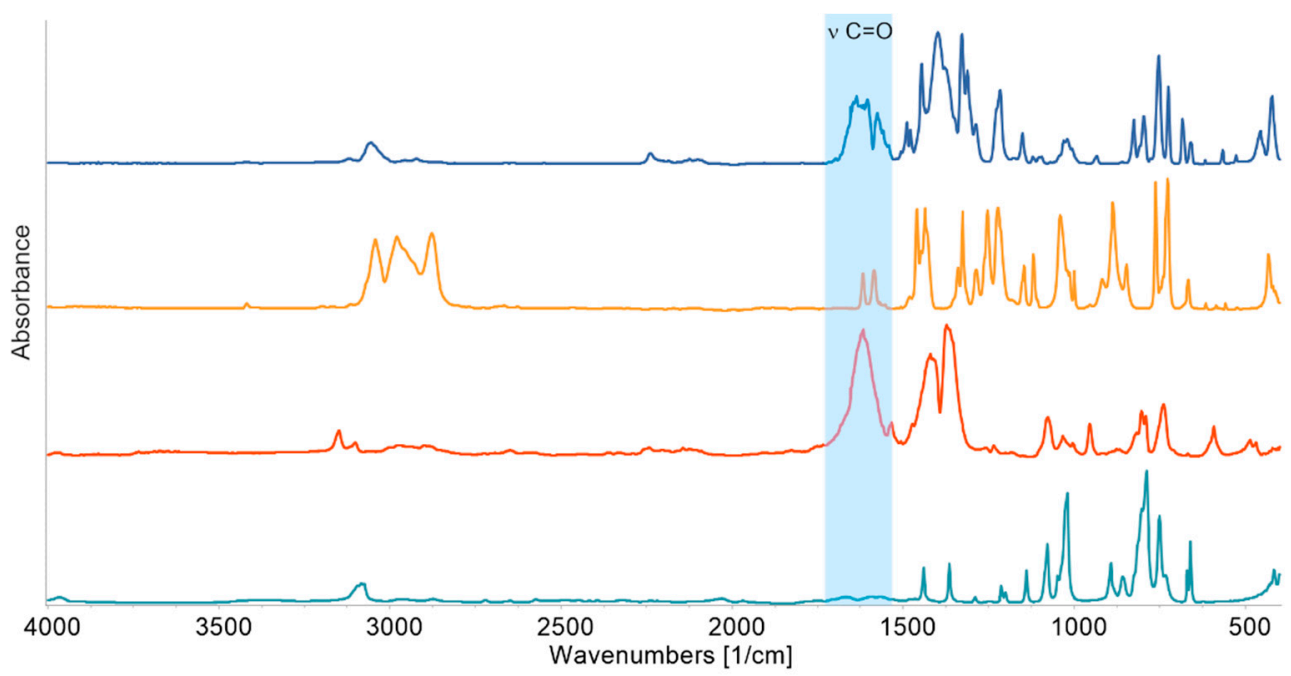

Figure 7. Stacked DRIFT (diffuse reflectance infrared Fourier transform) spectra of the reactions of 4 before (green trace) and after treatment with $\mathrm{CO}_{2}$ (orange trace) as well as $\mathbf{5}$ before (yellow) and after treatment with $\mathrm{CO}_{2}$ (blue) from bottom to top. The region for $\mathrm{C}-\mathrm{O}$ vibrations is highlighted in blue.

\subsection{Difference between Pyrazolates and Pyrrolates/Carbazolates}

Based on our findings, it can be hypothesized that $\mathrm{CO}_{2}$ insertion into the $\mathrm{Ce}-\mathrm{N}(\mathrm{RR} / \mathrm{pz})$ bond is mainly affected by the sterics of the pyrazole substituents. This is clearly indicated by the performance of $\left[\mathrm{Ce}\left(\mathrm{Me}_{2} \mathrm{pz}\right)_{4}\right]_{2}$ being far superior to that of $\mathrm{Ce}\left(t \mathrm{Bu}_{2} \mathrm{pz}\right)_{4}$. Accordingly, any significant electronic effect caused by differently alkyl-substituted pyrazolato ligands can be ruled out. However, our results suggest that the reversibility of the $\mathrm{CO}_{2}$ insertion is most likely driven by the two adjacent $\mathrm{N}$-donor atoms of the pyrazolato ligand, preserving a $\mathrm{Ce}-\mathrm{N}$ coordination also in the $\mathrm{Ce}-\mathrm{pz} \cdot \mathrm{CO}_{2}$ fragments (Scheme 3 ). Apparently, the formation of a five-membered heterocyclic ring with $\kappa^{2}(N, O)$ coordination mode is outperforming a four-membered ring with terminal $\kappa^{2}(O, O)$ carboxylato coordination. The latter $\kappa^{2}(O, O)$ coordination would result from the insertion of $\mathrm{CO}_{2}$ into the $\mathrm{Ce}-\mathrm{N}(\mathrm{pyr})$ or $\mathrm{Ce}-\mathrm{N}(\mathrm{cbz})$ bonds (Scheme 3). Note that any reversible $\mathrm{CO}_{2}$ insertion has not yet been evidenced for such simple carbamates.

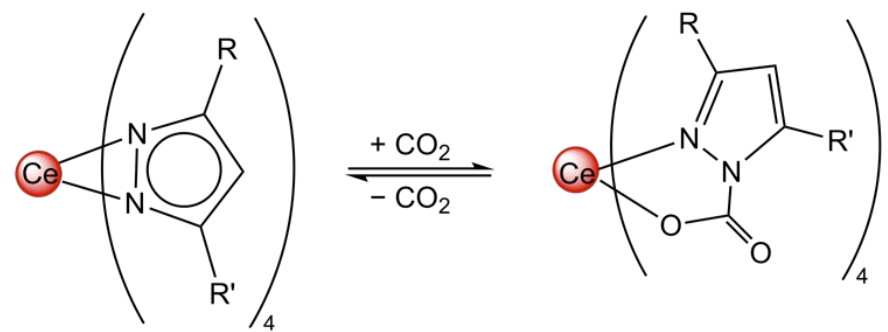

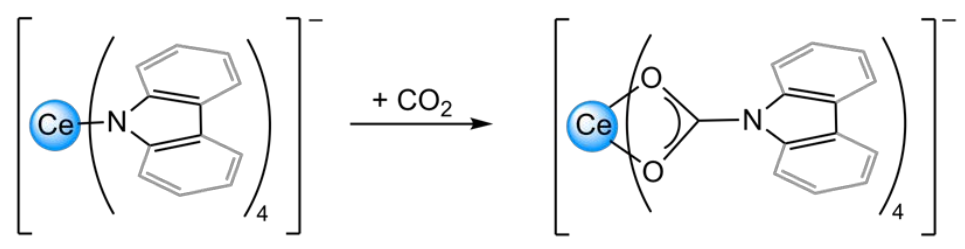

Scheme 3. Reversible and irreversible $\mathrm{CO}_{2}$ insertion into $\mathrm{Ce}-\mathrm{N}(\mathrm{pz})$ and $\mathrm{Ce}-\mathrm{N}(\mathrm{pyr}) / \mathrm{Ce}-\mathrm{N}(\mathrm{cbz})$ bonds, respectively. 


\section{Materials and Methods}

\subsection{General Procedures}

All manipulations were performed under an inert atmosphere (Ar) using a glovebox (MBraun 200B; $<0.1 \mathrm{ppm}_{2},<0.1 \mathrm{ppm} \mathrm{H}_{2} \mathrm{O}$ ), or according to standard Schlenk techniques in oven-dried glassware. The solvents were purified with Grubbs-type columns (MBraun SPS, solvent purification system) and stored in a glovebox. $\mathrm{Ce}\left[\mathrm{N}\left(\mathrm{SiHMe}_{2}\right)_{2}\right]_{4} \mathrm{Li}$ (thf), $\mathrm{Ce}\left[\mathrm{N}\left(\mathrm{SiHMe}_{2}\right)_{2}\right]_{4}$, and $\mathrm{Ce}\left(\mathrm{Bu}_{2} \mathrm{pz}\right)_{4}(\mathbf{1})$ were synthesized according to published procedures [65-67]. $\mathrm{HMe}_{2} \mathrm{pz}, \mathrm{H} t \mathrm{Bu}_{2} \mathrm{pz}$, pyrrole, and carbazole were purchased from Sigma Aldrich (St. Louis, MO, USA) and used as received. $\mathrm{HPh}_{2} \mathrm{pz}$ and $\mathrm{H} t \mathrm{BuMepz}$ were synthesized according to the literature [77]. $\mathrm{C}_{6} \mathrm{D}_{6}$, toluene- $d_{8}$, and THF- $d_{8}$ were purchased from Euriso-top (Saint-Aubin, France) and pre-dried over NaK alloy and filtered off prior use; THF- $d_{8}$ was re-condensed. NMR spectra were recorded at $26^{\circ} \mathrm{C}$ on a Bruker AVII+400 $\left({ }^{1} \mathrm{H}: 400.13 \mathrm{MHz}\right)$ or a Bruker AVIIIHD-300 $\left({ }^{1} \mathrm{H}: 300.13 \mathrm{MHz},{ }^{7} \mathrm{Li} 116.64 \mathrm{MHz}\right)$ using J. Young-valved NMR tubes. ${ }^{1} \mathrm{H}$ NMR shifts are referenced to a solvent resonance and reported in parts per million (ppm) relative to tetramethylsilane. ${ }^{7} \mathrm{Li}$ NMR spectra are reported relative to $\mathrm{LiCl}$. Analyses of NMR spectra were performed with ACD/NMR Processor Academic Edition (product version: 12.01). Infrared spectra were recorded on a ThermoFisher Scientific (Waltham, MA, USA) NICOLET 6700 FTIR $\left(\widetilde{v}=4000-400 \mathrm{~cm}^{-1}\right)$ spectrometer using a DRIFTS chamber with dry $\mathrm{KBr} /$ sample mixtures and $\mathrm{KBr}$ windows. Elemental analysis $(\mathrm{C}, \mathrm{H}$, and $\mathrm{N})$ was performed on an Elementar vario MICRO cube. In situ IR spectra were recorded on a METTLER TOLEDO (Columbus, OH, USA) ReactIR 15. For details on XRD analyses and crystallographic data, see Supporting information.

\subsection{Synthesis of $\mathrm{Ce}\left(\mathrm{Ph}_{2} \mathrm{pz}\right)_{4} \cdot \mathrm{tol}$ (2)}

$\mathrm{Ce}\left[\mathrm{N}\left(\mathrm{SiHMe}_{2}\right)_{2}\right]_{4}(0.40 \mathrm{~g}, 0.60 \mathrm{mmol})$ in $n$-hexane $(2 \mathrm{~mL})$ was added to a suspension of $\mathrm{HPh}_{2} \mathrm{pz}(0.33 \mathrm{~g}, 2.4 \mathrm{mmol})$ in toluene $(2 \mathrm{~mL})$. After $1 \mathrm{~h}$, all volatiles were removed under reduced pressure. Crystallization from concentrated toluene solutions produced $\mathbf{2}$ as dark purple crystals. Yield: $0.52 \mathrm{~g}(0.47 \mathrm{mmol}, 79 \%) .{ }^{1} \mathrm{H}$ NMR $\left(\mathrm{C}_{6} \mathrm{D}_{6}, 400.13 \mathrm{MHz}, 26{ }^{\circ} \mathrm{C}\right):=7.78$ $(\mathrm{m}, 16 \mathrm{H}, \mathrm{C}-\mathrm{H} \mathrm{Ph}), 7.11(\mathrm{~s}, 4 \mathrm{H}, \mathrm{C}-\mathrm{H} \mathrm{pz}), 6.91(\mathrm{~m}, 24 \mathrm{H}, \mathrm{C}-\mathrm{H} \mathrm{Ph}) \mathrm{ppm}$; IR (DRIFT): $\widetilde{v}=3064(w), 3036(w), 2916(w), 1944(w), 1883(w), 1807(w), 1755(w), 1682(w), 1602(w)$, $1562(\mathrm{w}), 1489(\mathrm{w}), 1467(\mathrm{~s}), 1421(\mathrm{~m}), 1401(\mathrm{~m}), 1335(\mathrm{w}), 1282(\mathrm{w}), 1254(\mathrm{w}), 1151(\mathrm{w})$, $1103(\mathrm{w}), 1072(\mathrm{w}), 1018(\mathrm{~m}), 999(\mathrm{~m}), 965(\mathrm{~m}), 914(\mathrm{w}), 837(\mathrm{w}), 809(\mathrm{w}), 760(\mathrm{~s}), 731(\mathrm{~s})$, $700(\mathrm{~s}), 692(\mathrm{~m}), 678(\mathrm{~m}), 666(\mathrm{w}), 537(\mathrm{w}), 481(\mathrm{w}), 465(\mathrm{w}), 429(\mathrm{~m}), 422(\mathrm{~m}), 405(\mathrm{w}) \mathrm{cm}^{-1}$; elemental analysis (\%) calcd. for $\mathrm{C}_{67} \mathrm{H}_{52} \mathrm{CeN}_{8}$ (1109.33): C 72.54, $\mathrm{H} 4.73, \mathrm{~N} 10.10$; found: $\mathrm{C}$ 72.40, H 4.52, N 10.68.

\subsection{Synthesis of $\left[\mathrm{Ce}(t \mathrm{BuMepz})_{4}\right]_{n}$ (3)}

$\mathrm{Ce}\left[\mathrm{N}\left(\mathrm{SiHMe}_{2}\right)_{2}\right]_{4}(0.40 \mathrm{~g}, 0.60 \mathrm{mmol})$ in toluene $(2 \mathrm{~mL})$ was added to a suspension of HtBuMepz $(0.53 \mathrm{~g}, 2.4 \mathrm{mmol})$ in toluene $(2 \mathrm{~mL})$. After $2 \mathrm{~h}$, all volatiles were removed in vacuo, producing 3 as a dark red sticky solid. Yield of the crude product: $0.41 \mathrm{~g} .{ }^{1} \mathrm{H}$ $\operatorname{NMR}\left(\mathrm{C}_{6} \mathrm{D}_{6}, 400.13 \mathrm{MHz}, 26^{\circ} \mathrm{C}\right):=6.15(\mathrm{~s}, 4 \mathrm{H}, \mathrm{C}-\mathrm{H} \mathrm{pz}), 2.22(\mathrm{~s}, 12 \mathrm{H}, \mathrm{Me}), 1.24(\mathrm{~s}, 36 \mathrm{H}$, tBu) ppm; IR (DRIFT): $\widetilde{v}=3105$ (w), 2961 (vs), 2924 (s), 2901 (s), 2862 (m), 1558 (w), $1508(\mathrm{~s})$, $1474(\mathrm{~m}), 1458(\mathrm{~m}), 1425(\mathrm{~s}), 1387(\mathrm{~m}), 1362(\mathrm{~m}), 1291(\mathrm{w}), 1237(\mathrm{~s}), 1210(\mathrm{w}), 1124(\mathrm{w})$, $1084(\mathrm{w}), 1032(\mathrm{w}), 1020(\mathrm{w}), 994(\mathrm{~m}), 962(\mathrm{w}), 819(\mathrm{w}), 797(\mathrm{~m}), 718(\mathrm{w}), 700(\mathrm{w}), 686(\mathrm{w})$, $567(\mathrm{w}), 507(\mathrm{~m}) \mathrm{cm}^{-1}$; elemental analysis (\%) calcd. for $\mathrm{C}_{32} \mathrm{H}_{52} \mathrm{CeN}_{8}$ (688.94): C 55.79, $\mathrm{H}$ 7.61, N 16.26; found: C 57.17, H 7.49, N 16.29. The slightly increased carbon value might be a result of retained solvent.

\subsection{Synthesis of $\left[C e_{2}(\text { pyr })_{6}(\mu-p y r)_{2}(\text { thf })_{2}\right]\left[L i(\text { thf })_{4}\right]_{2}$ (4)}

Pyrrole (141 mg, $2.11 \mathrm{mmol})$ in $n$-hexane ( $3 \mathrm{~mL}$ ) was added to a stirred solution of $\mathrm{Ce}\left[\mathrm{N}\left(\mathrm{SiHMe}_{2}\right)_{2}\right]_{4} \mathrm{Li}$ (thf) $(394 \mathrm{mg}, 0.526 \mathrm{mmol})$ in $n$-hexane $(5 \mathrm{~mL})$. Immediately, a colorless precipitate was formed. After $1 \mathrm{~h}$, all volatiles were removed under reduced pressure. The resulting solid was recrystallized from THF, producing 4 as colorless crystals. Yield: $189 \mathrm{mg}$ (0.122 mmol, $46 \%$ ). ${ }^{1} \mathrm{H}$ NMR (THF- $d_{8} ; 400.11 \mathrm{MHz}, 26{ }^{\circ} \mathrm{C}$ ) $\delta=7.39$ (bs), 4.23 (bs) ppm; ${ }^{7} \mathrm{Li}$ 
NMR (THF- $\left.d_{8}, 116.64 \mathrm{MHz}, 25^{\circ} \mathrm{C}\right) \delta=2.0$ ppm. DRIFTS: $\widetilde{v}=3085(\mathrm{w}), 1441(\mathrm{w}), 1365(\mathrm{w})$, 1213 (vw), 1200 (vw), $1140(\mathrm{w}), 1078(\mathrm{~m}), 1048(\mathrm{w}), 1021(\mathrm{~s}), 894(\mathrm{w}), 858(\mathrm{w}), 789(\mathrm{vs}), 751$ $(\mathrm{m}), 670(\mathrm{w}), 660(\mathrm{~m}), 416(\mathrm{w}) \mathrm{cm}^{-1}$; elemental analysis (\%) calcd. for $\mathrm{C}_{72} \mathrm{H}_{112} \mathrm{Ce}_{2} \mathrm{Li}_{2} \mathrm{~N}_{8} \mathrm{O}_{10}$ (1543.85): C 56.02, H 7.31, N 7.36; found: C 46.96, H 3.90, N 13.74. Calculated without THF donor ligands for $\mathrm{C}_{42} \mathrm{H}_{54} \mathrm{Ce}_{2} \mathrm{~N}_{8} \mathrm{O}_{2}$ (983.18): C 51.31, H 5.54, N 11.40. On multiple attempts, no better elemental analysis could be obtained.

\subsection{Synthesis of $\left[\mathrm{Ce}(\mathrm{cbz})_{4}\left(\right.\right.$ thf $\left._{2}\right]\left[\mathrm{Li}(\text { thf })_{4}\right]$ (5)}

$\mathrm{Ce}\left[\mathrm{N}\left(\mathrm{SiHMe}_{2}\right)_{2}\right]_{4} \mathrm{Li}(\mathrm{thf})(406 \mathrm{mg}, 0.557 \mathrm{mmol})$ in $n$-hexane $(5 \mathrm{~mL})$ was added to a stirred suspension of carbazole (363 mg, $2.23 \mathrm{mmol}$ ) in $n$-hexane $(5 \mathrm{~mL})$. After $1 \mathrm{~h}$, a yellow precipitate formed, and volatiles were removed under reduced pressure. The resulting solid was recrystallized from $\mathrm{THF} / \mathrm{Et}_{2} \mathrm{O}(1: 1)$, giving 5 as off-white crystals. Yield: $486 \mathrm{mg}$ (0.415 mmol, 74\%). ${ }^{1} \mathrm{H}$ NMR (THF- $\left.d_{8} ; 400.11 \mathrm{MHz}, 26{ }^{\circ} \mathrm{C}\right) \delta=8.64(\mathrm{~d}), 7.90(\mathrm{bs}), 7.70(\mathrm{~d})$, 7.32 (d), 7.02 (bs), 6.70 (bs) 6.28 (s), 6.04 (s), 5.30 (s), 4.22 (d), 3.62 (s, $\alpha-C H($ thf)), 1.77 (s, $\beta-\mathrm{CH}(\mathrm{thf})), 0.33$ (bs), -10.16 (bs) ppm; ${ }^{7} \mathrm{Li} \mathrm{NMR}\left(\mathrm{THF}-d_{8}, 116.64 \mathrm{MHz}, 25^{\circ} \mathrm{C}\right) \delta$ : $-0.3 \mathrm{ppm}$. DRIFTS: $\widetilde{v}=3418(\mathrm{vw}), 3054(\mathrm{w}), 2979(\mathrm{w}), 2878(\mathrm{w}), 1635(\mathrm{~m}), 1576(\mathrm{~m}), 1541(\mathrm{~m}), 1489(\mathrm{~m})$, 1479 (m), 1447 (s), 1395 (vs), 1329 (vs), 1312 (s), 1287 (m), 1216 (m), 1151 (w), 1121 (vw), 1043 (w), $934(\mathrm{vw}), 889(\mathrm{vw}), 826(\mathrm{~m}), 797(\mathrm{~m}), 753(\mathrm{~s}), 725(\mathrm{~m}), 684(\mathrm{~m}), 658(\mathrm{w}), 617(\mathrm{vw}), 567$ (vw), $526(\mathrm{vw}), 458(\mathrm{w}), 425(\mathrm{~m}) \mathrm{cm}^{-1}$; elemental analysis (\%) calcd. for $\mathrm{C}_{72} \mathrm{H}_{80} \mathrm{CeLiN}_{4} \mathrm{O}_{6}$ (1244.51): C 69.49, H 6.48, N 4.50; found: C 68.42, H 6.42, N 3.97.

\section{Conclusions}

The feasibility of $\mathrm{CO}_{2}$ insertion reactions was further substantiated for homoleptic ceric pyrazolates [Ce(RR'pz $)_{4}$ ]. Crucially, with increasing bulkiness of the substituents $\mathrm{R} / \mathrm{R}^{\prime}$ on the pyrazolato ligand, the insertion of carbon dioxide becomes increasingly hindered; therefore, the least bulky dimethyl-substituted pyrazolato ligand performed best in $\mathrm{CO}_{2}$ insertions. En route to homoleptic $\mathrm{Ce}^{\mathrm{IV}}$ pyrrolates and carbazolates, we were able to isolate cerous ate complexes $\left[\mathrm{Ce}_{2}(\mathrm{pyr})_{6}(\mu \text {-pyr })_{2}(\mathrm{thf})_{2}\right]\left[\mathrm{Li}(\mathrm{thf})_{4}\right]_{2}$ and $\left[\mathrm{Ce}(\mathrm{cbz})_{4}(\text { thf })_{2}\right]\left[\mathrm{Li}(\mathrm{thf})_{4}\right]$. Such $\mathrm{Ce}(\mathrm{III})$ pyrrolates and carbazolates are also capable of $\mathrm{CO}_{2}$ activation, but most likely in an irreversible manner. Oxidation attempts to form ceric pyrrolate or carbazolate compounds were conducted; however, the structural elucidation of any $\mathrm{Ce}^{\mathrm{IV}}$ species was not feasible.

Supplementary Materials: The following are available online. The ${ }^{1} \mathrm{H}(2,3,4$, and 5, and their reactions with $\mathrm{CO}_{2}$ ) and ${ }^{7} \mathrm{Li}(4$ and 5). NMR spectra as well as selected crystallographic data for compounds 2, 4, and 5 are available online. Complete crystallographic data can be obtained free of charge from The Cambridge Crystallographic Data Centre via www.ccdc.cam.ac.uk/data_request/cif, Deposition Number 2069959-2069961.

Author Contributions: All reactions and analyses described were planned and conducted by U.B., A.J. and J.R. Analyses included NMR and DRIFT spectroscopies as well as elemental analysis. Publication writing was completed by U.B. and R.A. The XRD analyses were performed by U.B. and C.M.-M. All authors have read and agreed to the published version of the manuscript.

Funding: This research received no external funding.

Institutional Review Board Statement: Not applicable.

Informed Consent Statement: Not applicable.

Data Availability Statement: Not applicable.

Acknowledgments: We thank Doris Kunz for providing access to ReactIR 15 for in situ IR measurements.

Conflicts of Interest: The authors declare no conflict of interest. The funders had no role in the design of the study; in the collection, analyses, or interpretation of data; in the writing of the manuscript, or in the decision to publish the results.

Sample Availability: Samples of the compounds are not available from authors. 


\section{References}

1. Hou, Z.; Wakatsuki, Y. Reactions of Ketones with Low-Valent Lanthanides: Isolation and Reactivity of Lanthanide Ketyl and Ketone Dianion Complexes. In Lanthanides: Chemistry and Use in Organic Synthesis; Kobayashi, S., Ed.; Topics in Organometallic Chemistry; Springer: Berlin/Heidelberg, Germany, 1999; pp. 233-253, ISBN 978-3-540-69801-2.

2. Bayer, U.; Anwander, R. Carbonyl Group and Carbon Dioxide Activation by Rare-Earth-Metal Complexes. Dalton Trans. 2020, 49, 17472-17493. [CrossRef] [PubMed]

3. Martín, C.; Fiorani, G.; Kleij, A.W. Recent Advances in the Catalytic Preparation of Cyclic Organic Carbonates. ACS Catal. 2015, 5, 1353-1370. [CrossRef]

4. Grice, K.A. Carbon Dioxide Reduction with Homogenous Early Transition Metal Complexes: Opportunities and Challenges for Developing $\mathrm{CO}_{2}$ Catalysis. Coord. Chem. Rev. 2017, 336, 78-95. [CrossRef]

5. Huang, J.; Worch, J.C.; Dove, A.P.; Coulembier, O. Update and Challenges in Carbon Dioxide-Based Polycarbonate Synthesis. ChemSusChem 2020, 13, 469-487. [CrossRef] [PubMed]

6. Bresciani, G.; Biancalana, L.; Pampaloni, G.; Marchetti, F. Recent Advances in the Chemistry of Metal Carbamates. Molecules 2020, 25, 3603. [CrossRef]

7. Falkowski, P.; Scholes, R.J.; Boyle, E.; Canadell, J.; Canfield, D.; Elser, J.; Gruber, N.; Hibbard, K.; Högberg, P.; Linder, S.; et al. The Global Carbon Cycle: A Test of Our Knowledge of Earth as a System. Science 2000, 290, 291-296. [CrossRef]

8. Solomon, S.; Plattner, G.-K.; Knutti, R.; Friedlingstein, P. Irreversible Climate Change Due to Carbon Dioxide Emissions. Proc. Natl. Acad. Sci. USA 2009, 106, 1704-1709. [CrossRef]

9. Haszeldine, R.S. Carbon Capture and Storage: How Green Can Black Be? Science 2009, 325, 1647-1652. [CrossRef] [PubMed]

10. Keith, D.W. Why Capture $\mathrm{CO}_{2}$ from the Atmosphere? Science 2009, 325, 1654-1655. [CrossRef] [PubMed]

11. von der Assen, N.; Voll, P.; Peters, M.; Bardow, A. Life Cycle Assessment of $\mathrm{CO}_{2}$ Capture and Utilization: A Tutorial Review. Chem. Soc. Rev. 2014, 43, 7982-7994. [CrossRef] [PubMed]

12. D'Alessandro, D.M.; Smit, B.; Long, J.R. Carbon Dioxide Capture: Prospects for New Materials. Angew. Chem. Int. Ed. 2010, 49, 6058-6082. [CrossRef] [PubMed]

13. Yu, C.-H.; Huang, C.-H.; Tan, C.-S. A Review of $\mathrm{CO}_{2}$ Capture by Absorption and Adsorption. Aerosol Air Qual. Res. 2012, 12, 745-769. [CrossRef]

14. Sumida, K.; Rogow, D.L.; Mason, J.A.; McDonald, T.M.; Bloch, E.D.; Herm, Z.R.; Bae, T.-H.; Long, J.R. Carbon Dioxide Capture in Metal-Organic Frameworks. Chem. Rev. 2012, 112, 724-781. [CrossRef] [PubMed]

15. Sanz-Pérez, E.S.; Murdock, C.R.; Didas, S.A.; Jones, C.W. Direct Capture of $\mathrm{CO}_{2}$ from Ambient Air. Chem. Rev. 2016, 116, 11840-11876. [CrossRef] [PubMed]

16. Lin, Y.; Kong, C.; Zhang, Q.; Chen, L. Metal-Organic Frameworks for Carbon Dioxide Capture and Methane Storage. Adv. Energy Mater. 2017, 7. [CrossRef]

17. Sakakura, T.; Choi, J.-C.; Yasuda, H. Transformation of Carbon Dioxide. Chem. Rev. 2007, 107, 2365-2387. [CrossRef] [PubMed]

18. Centi, G.; Perathoner, S. Opportunities and Prospects in the Chemical Recycling of Carbon Dioxide to Fuels. Catal. Today 2009, 148, 191-205. [CrossRef]

19. Cokoja, M.; Bruckmeier, C.; Rieger, B.; Herrmann, W.A.; Kühn, F.E. Transformation of Carbon Dioxide with Homogeneous Transition-Metal Catalysts: A Molecular Solution to a Global Challenge? Angew. Chem. Int. Ed. 2011, 50, 8510-8537. [CrossRef] [PubMed]

20. Aresta, M.; Dibenedetto, A.; Angelini, A. Catalysis for the Valorization of Exhaust Carbon: From $\mathrm{CO}_{2}$ to $\mathrm{Chemicals}$ Materials, and Fuels. Technological Use of $\mathrm{CO}_{2}$. Chem. Rev. 2014, 114, 1709-1742. [CrossRef]

21. Liu, Q.; Wu, L.; Jackstell, R.; Beller, M. Using Carbon Dioxide as a Building Block in Organic Synthesis. Nat. Commun. 2015, 6, 5933. [CrossRef]

22. Artz, J.; Müller, T.E.; Thenert, K.; Kleinekorte, J.; Meys, R.; Sternberg, A.; Bardow, A.; Leitner, W. Sustainable Conversion of Carbon Dioxide: An Integrated Review of Catalysis and Life Cycle Assessment. Chem. Rev. 2018, 118, 434-504. [CrossRef] [PubMed]

23. Modak, A.; Bhanja, P.; Dutta, S.; Chowdhury, B.; Bhaumik, A. Catalytic Reduction of $\mathrm{CO}_{2}$ into Fuels and Fine Chemicals. Green Chem. 2020, 22, 4002-4033. [CrossRef]

24. Vitanova, D.V.; Hampel, F.; Hultzsch, K.C. Rare Earth Metal Complexes Based on $\beta$-Diketiminato and Novel Linked Bis( $\beta$ Diketiminato) Ligands: Synthesis, Structural Characterization and Catalytic Application in Epoxide/ $\mathrm{CO}_{2}-\mathrm{Copolymerization}$. J. Organomet. Chem. 2005, 690, 5182-5197. [CrossRef]

25. Cui, D.; Nishiura, M.; Hou, Z. Alternating Copolymerization of Cyclohexene Oxide and Carbon Dioxide Catalyzed by Organo Rare Earth Metal Complexes. Macromolecules 2005, 38, 4089-4095. [CrossRef]

26. Lazarov, B.B.; Hampel, F.; Hultzsch, K.C. Synthesis and Structural Characterization of $\beta$-Diketiminato Yttrium Complexes and Their Application in Epoxide/ $\mathrm{CO}_{2}$-Copolymerization. Z. Anorg. Allg. Chem. 2007, 633, 2367-2373. [CrossRef]

27. Cui, D.; Nishiura, M.; Tardif, O.; Hou, Z. Rare-Earth-Metal Mixed Hydride/Aryloxide Complexes Bearing Mono(Cyclopentadienyl) Ligands. Synthesis, $\mathrm{CO}_{2}$ Fixation, and Catalysis on Copolymerization of $\mathrm{CO}_{2}$ with Cyclohexene Oxide. Organometallics 2008, 27, 2428-2435. [CrossRef]

28. Zhang, Z.; Cui, D.; Liu, X. Alternating Copolymerization of Cyclohexene Oxide and Carbon Dioxide Catalyzed by Noncyclopentadienyl Rare-Earth Metal Bis(Alkyl) Complexes. J. Polym. Sci. Part A Polym. Chem. 2008, 46, 6810-6818. [CrossRef] 
29. Decortes, A.; Haak, R.M.; Martín, C.; Belmonte, M.M.; Martin, E.; Benet-Buchholz, J.; Kleij, A.W. Copolymerization of CO 2 and Cyclohexene Oxide Mediated by Yb(Salen)-Based Complexes. Macromolecules 2015, 48, 8197-8207. [CrossRef]

30. Xu, B.; Wang, P.; Lv, M.; Yuan, D.; Yao, Y. Transformation of Carbon Dioxide into Oxazolidinones and Cyclic Carbonates Catalyzed by Rare-Earth-Metal Phenolates. ChemCatChem 2016, 8, 2466-2471. [CrossRef]

31. Yasuda, H. Organo-Rare-Earth-Metal Initiated Living Polymerizations of Polar and Nonpolar Monomers. J. Organomet. Chem. 2002, 647, 128-138. [CrossRef]

32. Ion, A.; Parvulescu, V.; Jacobs, P.; de Vos, D. Sc and Zn-Catalyzed Synthesis of Cyclic Carbonates from CO 2 and Epoxides. Appl. Catal. Gen. 2009, 363, 40-44. [CrossRef]

33. Qin, J.; Wang, P.; Li, Q.; Zhang, Y.; Yuan, D.; Yao, Y. Catalytic Production of Cyclic Carbonates Mediated by Lanthanide Phenolates under Mild Conditions. Chem. Commun. 2014, 50, 10952-10955. [CrossRef]

34. Wang, C.; Liu, X.; Dai, Z.; Sun, Y.; Tang, N.; Wu, J. Yttrium Complex Supported by a Sterically Encumbering N-Anchored Tris-Arylphenoxide Ligand: Heteroselective ROP of Rac-Lactide and $\mathrm{CO}_{2}$ /Epoxide Coupling. Inorg. Chem. Commun. 2015, 56, 69-72. [CrossRef]

35. Martínez, J.; Fernández-Baeza, J.; Sánchez-Barba, L.F.; Castro-Osma, J.A.; Lara-Sánchez, A.; Otero, A. An Efficient and Versatile Lanthanum Heteroscorpionate Catalyst for Carbon Dioxide Fixation into Cyclic Carbonates. ChemSusChem 2017, 10, 2886-2890. [CrossRef]

36. Zhao, Z.; Qin, J.; Zhang, C.; Wang, Y.; Yuan, D.; Yao, Y. Recyclable Single-Component Rare-Earth Metal Catalysts for Cycloaddition of $\mathrm{CO}_{2}$ and Epoxides at Atmospheric Pressure. Inorg. Chem. 2017, 56, 4568-4575. [CrossRef] [PubMed]

37. Sodpiban, O.; Gobbo, S.D.; Barman, S.; Aomchad, V.; Kidkhunthod, P.; Ould-Chikh, S.; Poater, A.; D’Elia, V.; Basset, J.-M. Synthesis of Well-Defined Yttrium-Based Lewis Acids by Capturing a Reaction Intermediate and Catalytic Application for Cycloaddition of $\mathrm{CO}_{2}$ to Epoxides under Atmospheric Pressure. Catal. Sci. Technol. 2019, 9, 6152-6165. [CrossRef]

38. Bayer, U.; Werner, D.; Maichle-Mössmer, C.; Anwander, R. Effective and Reversible Carbon Dioxide Insertion into Cerium Pyrazolates. Angew. Chem. Int. Ed. 2020, 59, 5830-5836. [CrossRef] [PubMed]

39. Bayer, U.; Liang, Y.; Anwander, R. Cerium Pyrazolates Grafted onto Mesoporous Silica SBA-15: Reversible $\mathrm{CO}_{2} \mathrm{Uptake}$ and Catalytic Cycloaddition of Epoxides and Carbon Dioxide. Inorg. Chem. 2020, 59, 14605-14614. [CrossRef] [PubMed]

40. Bordwell, F.G. Equilibrium Acidities in Dimethyl Sulfoxide Solution. Acc. Chem. Res. 1988, 21, 456-463. [CrossRef]

41. Bochkarev, M.; Fedorova, E.A.; Radkov, Y.F.; Ya, S.; Kalinina, G.S.; Razuvaev, G.A. Carbon Dioxide Fixation by Lanthanide Complexes. J. Organomet. Chem. 1983, 258, C29-C33. [CrossRef]

42. Radkov, Y.F.; Fedorova, E.A.; Khorshev, S.Y.; Kalinina, G.S.; Bochkarev, M.N.; Razuvaev, G.A. Reactions of Carbon Dioxide with Bis(Trimethylsilyl)Amino Derivaties of Lanthanides. Zhur. Obshchei Khimii 1986, 56, 386-389.

43. Yin, H.; Carroll, P.J.; Schelter, E.J. Reactions of a cerium(III) amide with heteroallenes: Insertion, silyl-migration and de-insertion. Chem. Commun. 2016, 52, 9813-9816. [CrossRef] [PubMed]

44. Jenter, J.; Gamer, M.T.; Roesky, P.W. 2,5-Bis\{N-(2,6-Diisopropylphenyl)Iminomethyl\}pyrrolyl Complexes of the Divalent Lanthanides: Synthesis and Structures. Organometallics 2010, 29, 4410-4413. [CrossRef]

45. Wang, L.; Liu, D.; Cui, D. NNN-Tridentate Pyrrolyl Rare-Earth Metal Complexes: Structure and Catalysis on Specific Selective Living Polymerization of Isoprene. Organometallics 2012, 31, 6014-6021. [CrossRef]

46. Johnson, K.R.D.; Hannon, M.A.; Ritch, J.S.; Hayes, P.G. Thermally Stable Rare Earth Dialkyl Complexes Supported by a Novel Bis(Phosphinimine)Pyrrole Ligand. Dalton Trans. 2012, 41, 7873-7875. [CrossRef]

47. Kaneko, H.; Dietrich, H.M.; Schädle, C.; Maichle-Mössmer, C.; Tsurugi, H.; Törnroos, K.W.; Mashima, K.; Anwander, R. Synthesis of Rare-Earth-Metal Iminopyrrolyl Complexes from Alkyl Precursors: Ln $\rightarrow$ Al N-Ancillary Ligand Transfer. Organometallics 2013, 32, 1199-1208. [CrossRef]

48. Levine, D.S.; Tilley, T.D.; Andersen, R.A. Evidence for the Existence of Group 3 Terminal Methylidene Complexes. Organometallics 2017, 36, 80-88. [CrossRef]

49. Knott, J.P.; Hänninen, M.M.; Rautiainen, J.M.; Tuononen, H.M.; Hayes, P.G. Insights into the Decomposition Pathway of a Lutetium Alkylamido Complex via Intramolecular C-H Bond Activation. J. Organomet. Chem. 2017, 845, 135-143. [CrossRef]

50. Sampson, J.; Choi, G.; Akhtar, M.N.; Jaseer, E.A.; Theravalappil, R.; Garcia, N.; Agapie, T. Early Metal Di(Pyridyl) Pyrrolide Complexes with Second Coordination Sphere Arene $-\pi$ Interactions: Ligand Binding and Ethylene Polymerization. ACS Omega 2019, 4, 15879-15892. [CrossRef] [PubMed]

51. McPherson, J.N.; Galan, L.A.; Iranmanesh, H.; Massi, M.; Colbran, S.B. Synthesis and Structural, Redox and Photophysical Properties of Tris-(2,5-Di(2-Pyridyl)Pyrrolide) Lanthanide Complexes. Dalton Trans. 2019, 48, 9365-9375. [CrossRef]

52. Schumann, H.; Lee, P.R.; Dietrich, A. Organometallic Compounds of the Lanthanides, 57. Pyrrolyl Complexes of Yttrium and Lutetium. Molecular Structure of Dicyclopentadienyl(2,5-Dimethylpyrrolyl)(Tetrahydrofuran)Lutetium(III). Chem. Ber. 1990, 123, 1331-1334. [CrossRef]

53. Arndt, S.; Trifonov, A.; Spaniol, T.P.; Okuda, J.; Kitamura, M.; Takahashi, T. Metalation of Aromatic Heterocycles by Yttrium Alkyl Complexes That Contain a Linked Amido-Cyclopentadienyl Ligand: Synthesis, Structure and Lewis Base Adduct Formation. J. Organomet. Chem. 2002, 647, 158-166. [CrossRef]

54. Quitmann, C.C.; Müller-Buschbaum, K. $\left[\mathrm{Sm}\left(\mathrm{NH}_{3}\right)_{9}\right]\left[\mathrm{Sm}(\mathrm{Pyr})_{6}\right]$, ein komplexes Salz mit zwei homoleptischen Ionen aus der Synthese in flüssigem Ammoniak. Z. Anorg. Allg. Chem. 2005, 631, 564-568. [CrossRef] 
55. Arnold, P.L.; Cadenbach, T.; Marr, I.H.; Fyfe, A.A.; Bell, N.L.; Bellabarba, R.; Tooze, R.P.; Love, J.B. Homo- and Heteroleptic Alkoxycarbene f-Element Complexes and Their Reactivity towards Acidic N-H and C-H Bonds. Dalton Trans. 2014, 43, 14346-14358. [CrossRef]

56. Deacon, G.B.; Forsyth, C.M.; Gatehouse, B.M. Organoamido- and Aryloxo-Lanthanoids. I. The Preparation and Characterization of Some Lanthanoid(II) Organoamides, and the X-Ray Crystal Structure of Cis-Bis(Carbazol-9-Yl)Tetrakis(Tetrahydrofuran) Europium(II). Aust. J. Chem. 1990, 43, 795-806. [CrossRef]

57. Abrahams, C.T.; Deacon, G.B.; Gatehouse, B.M.; Ward, G.N. Cis-Bis(9-Carbazolyl)(1,2-Dimethoxyethane)-Cis-Bis(Tetrahydrofuran) Ytterbium(II). Acta Crystallogr. C 1994, 50, 504-507. [CrossRef]

58. Evans, W.J.; Rabe, G.W.; Ziller, J.W. Stereochemical Variability in Samarium(II) Reagents Using Carbazole as an Alternative to Iodide: Synthesis and Structure of Cis- $\left(\mathrm{C}_{12} \mathrm{H}_{8} \mathrm{~N}\right)_{2} \mathrm{Sm}(\mathrm{THF})_{4}$ and Trans- $\left(\mathrm{C}_{12} \mathrm{H}_{8} \mathrm{~N}\right)_{2} \mathrm{Sm}(\mathrm{N}-\mathrm{MeIm})_{4}$. Organometallics 1994, 13, 1641-1645. [CrossRef]

59. Quitmann, C.C.; Müller-Buschbaum, K. Verdrängung von $\eta^{6}-\pi$-Wechselwirkungen durch N-Donor-Liganden: Von eindimensionalen Samarium- und Ytterbium-Carbazolaten zu monomeren Einheiten mit N-Phenylpiperazin. Z. Anorg. Allg. Chem. 2005, 631, 350-354. [CrossRef]

60. Müller-Buschbaum, K.; Zurawski, A. On the Mechanisms of Electride Induced Synthesis of Ytterbium Carbazolates, Formation of Coordination Polymers by Condensation and Polymer Degradation by Chemical Scissors. Z. Anorg. Allg. Chem. 2007, 633, 2300-2304. [CrossRef]

61. Basalov, I.V.; Roşca, S.C.; Lyubov, D.M.; Selikhov, A.N.; Fukin, G.K.; Sarazin, Y.; Carpentier, J.-F.; Trifonov, A.A. Divalent Heteroleptic Ytterbium Complexes - Effective Catalysts for Intermolecular Styrene Hydrophosphination and Hydroamination. Inorg. Chem. 2014, 53, 1654-1661. [CrossRef] [PubMed]

62. Long, J.; Selikhov, A.N.; Mamontova, E.; Lyssenko, K.A.; Guari, Y.; Larionova, J.; Trifonov, A.A. Single-Molecule Magnet Behavior in Luminescent Carbazolyl Dy(III) Octahedral Complexes with a Quasi Linear N-Dy-N Angle. Dalton Trans. 2020, 49, 4039-4043. [CrossRef]

63. Eppinger, J.; Spiegler, M.; Hieringer, W.; Herrmann, W.A.; Anwander, R. C2-Symmetric Ansa-Lanthanidocene Complexes. Synthesis via Silylamine Elimination and $\beta$-SiH Agostic Rigidity. J. Am. Chem. Soc. 2000, 122, 3080-3096. [CrossRef]

64. Fraser, R.R.; Mansour, T.S.; Savard, S. Acidity Measurements on Pyridines in Tetrahydrofuran Using Lithiated Silylamines. J. Org. Chem. 1985, 50, 3232-3234. [CrossRef]

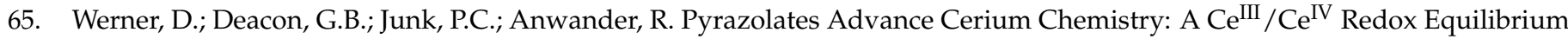
with Benzoquinone. Dalton Trans. 2017, 46, 6265-6277. [CrossRef]

66. Werner, D.; Deacon, G.B.; Junk, P.C.; Anwander, R. Cerium(III/IV) Formamidinate Chemistry, and a Stable Cerium(IV) Diolate. Chem. Eur. J. 2014, 20, 4426-4438. [CrossRef] [PubMed]

67. Bayer, U.; Bock, L.; Maichle-Mössmer, C.; Anwander, R. A Facile Route toward Ceric Silylamide $\left[\mathrm{Ce}\left\{\mathrm{N}\left(\mathrm{SiHMe}_{2}\right)_{2}\right\}_{4}\right]$. Eur. J. Inorg. Chem. 2020, 101-106. [CrossRef]

68. Evans, W.J.; Lee, D.S.; Rego, D.B.; Perotti, J.M.; Kozimor, S.A.; Moore, E.K.; Ziller, J.W. Expanding Dinitrogen Reduction Chemistry to Trivalent Lanthanides via the $\mathrm{LnZ}_{3} /$ Alkali Metal Reduction System: Evaluation of the Generality of Forming $\operatorname{Ln}_{2}\left(\mu-\eta^{2}: \eta^{2}-\mathrm{N}_{2}\right)$ Complexes via $\mathrm{LnZ}_{3} /$ K. J. Am. Chem. Soc. 2004, 126, 14574-14582. [CrossRef] [PubMed]

69. Williams, U.J.; Schneider, D.; Dorfner, W.L.; Maichle-Mössmer, C.; Carroll, P.J.; Anwander, R.; Schelter, E.J. Variation of Electronic Transitions and Reduction Potentials of Cerium(IV) Complexes. Dalton Trans. 2014, 43, 16197-16206. [CrossRef] [PubMed]

70. Hausen, H.-D.; Locke, K.; Weidlein*, J. Die Molekül- und Kristallstruktur von $\left(\mathrm{CH}_{3}\right)_{2} \mathrm{InNC}_{4} \mathrm{H}_{4}$. J. Organomet. Chem. 1992, 423, C1-C4. [CrossRef]

71. Hausen, H.-D.; Tödtmann, J.; Weidlein, J. $\left[\left(\mathrm{CH}_{3} \mathrm{C}\right)_{4} \mathrm{~N}-\left(\mathrm{CH}_{3}\right)_{2} \mathrm{Al} \cdots \mathrm{Cl} \cdots \mathrm{Al}\left(\mathrm{CH}_{3}\right)_{2}-\mathrm{N}\left(\mathrm{CCH}_{3}\right)_{4}\right]$ Li-Ein Ungewöhnlicher SandwichKomplex Des Lithiums. J. Organomet. Chem. 1994, 466, C1-C4. [CrossRef]

72. Hsueh, L.-F.; Chuang, N.-T.; Lee, C.-Y.; Datta, A.; Huang, J.-H.; Lee, T.-Y. Magnesium Complexes Containing $\eta^{1}$ - and $\eta^{3}$-Pyrrolyl or Ketiminato Ligands: Synthesis, Structural Investigation and $\epsilon$-Caprolactone Ring-Opening Polymerisation. Eur. J. Inorg. Chem. 2011, 5530-5537. [CrossRef]

73. Guo, Z.; Xu, Y.; Chao, J.; Wei, X. Lithium Organoaluminate Complexes as Catalysts for the Conversion of $\mathrm{CO}_{2}$ into $\mathrm{Cyclic}$ Carbonates. Eur. J. Inorg. Chem. 2020, 2835-2841. [CrossRef]

74. Crozier, A.R.; Bienfait, A.M.; Maichle-Mössmer, C.; Törnroos, K.W.; Anwander, R. A Homoleptic Tetravalent Cerium Silylamide. Chem. Commun. 2013, 49, 87-89. [CrossRef]

75. Schneider, D.; Spallek, T.; Maichle-Mössmer, C.; Törnroos, K.W.; Anwander, R. Cerium Tetrakis(Diisopropylamide)—A Useful Precursor for Cerium(IV) Chemistry. Chem. Commun. 2014, 50, 14763-14766. [CrossRef] [PubMed]

76. Gauld, R.M.; Kennedy, A.R.; McLellan, R.; Barker, J.; Reid, J.; Mulvey, R.E. Diverse Outcomes of $\mathrm{CO}_{2}$ Fixation Using Alkali Metal Amides Including Formation of a Heterobimetallic Lithium-Sodium Carbamato-Anhydride via Lithium-Sodium BisHexamethyldisilazide. Chem. Commun. 2019, 55, 1478-1481. [CrossRef] [PubMed]

77. Zelenin, K.N.; Tugusheva, A.R.; Yakimovich, S.I.; Alekseev, V.V.; Zerova, E.V. 5-Hydroxy-2-Pyrazolines and Some of Their 1-Substituted Analogs. Chem. Heterocycl. Compd. 2002, 38, 668-676. [CrossRef] 